\title{
Erratum to "Modulation of Human Cardiac Progenitors via Hypox- ia-ERK Circuit Improves their Functional Bioactivities" [Biomol. Ther. 21 (2013) 196-203]
}

\author{
Seok Yun Jung ${ }^{1, \dagger}$, Sung Hyun Choi ${ }^{2, \dagger}$, So Young Yoo ${ }^{1}$, Sang Hong Baek ${ }^{2, *}$ and Sang Mo Kwon ${ }^{1, *}$ \\ ${ }^{1}$ Laboratory of Vascular Medicine and Stem Cell Biology, Department of Physiology, School of Medicine, Pusan National University, \\ Yangsan 50612, \\ ${ }^{2}$ Laboratory of Cardiovascular Disease, Division of Cardiology, School of Medicine, The Catholic University of Korea, Seoul 06591, \\ Republic of Korea
}

The authors request to correct the myogenic differentiation method from ' 4 weeks' to ' 2 weeks' on 25 th line of left column of page 198. Also, the authors request to correct the hypoxia+U0126 group's day 0 picture in Fig. 7A on page 201.

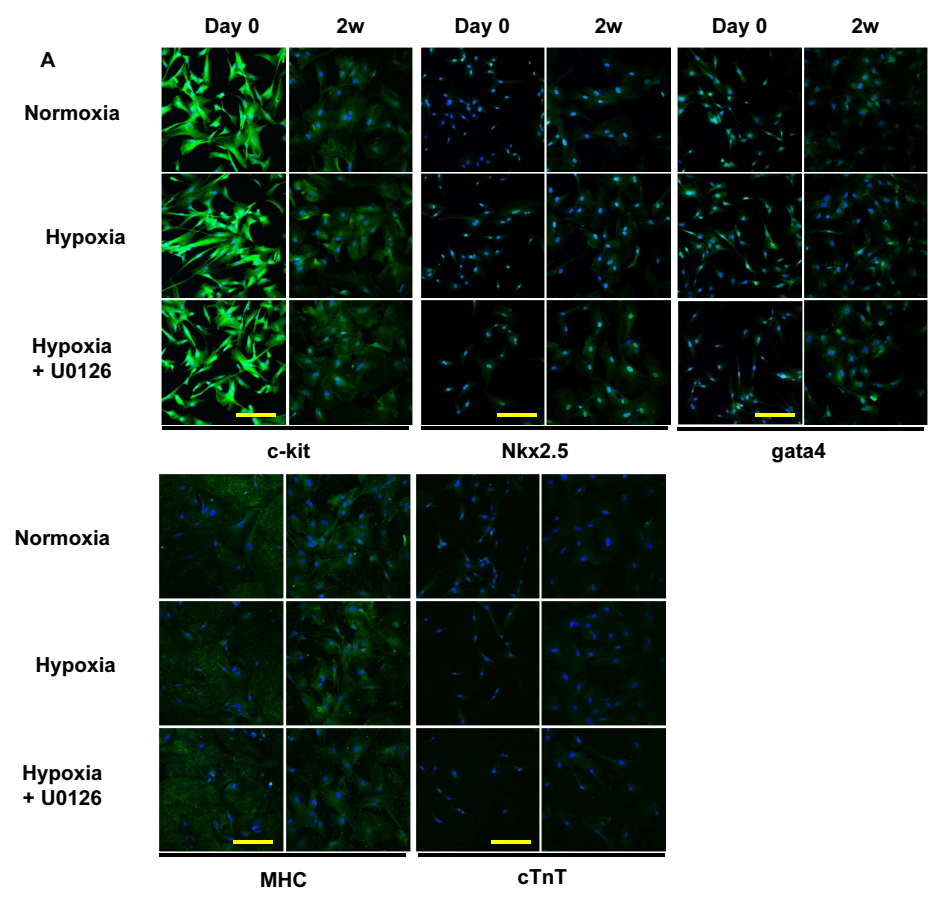

\section{Open Access https://doi.org/10.4062/biomolther.2021.697}

This is an Open Access article distributed under the terms of the Creative Commons Attribution Non-Commercial License (http://creativecommons.org/licenses/by-nc/4.0/) which permits unrestricted non-commercial use, distribution, and reproduction in any medium, provided the original work is properly cited.
DOI of original article : https://doi.org/10.4062/biomolther.2013.019

\section{*Corresponding Authors}

E-mail: smkwon323@hotmail.com (Kwon SM), whitesh@catholic.ac.kr (Baek SH)

Tel: +82-51-510-8075 (Kwon SM), +82-2-2258-6030 (Baek SH) Fax: +82-51-510-8076 (Kwon SM), +82-2-591-3614 (Baek SH)

${ }^{\dagger}$ The first two authors contributed equally to this work. 